\title{
PERBEDAAN KADAR GLUKOSADARAHPUASASEBELUM DAN SETELAHPEMBERIAN SARI BENGKUANG (Pachyrrhizuserosus) PADA WANITA PREDIABETES
}

\author{
Andriani Rizka Yasmina, Enny Probosari*) \\ Program Studi Ilmu Gizi Fakultas Kedokteran Universitas Diponegoro \\ Jl.Dr.Sutomo No.18, Semarang, Telp (024) 8453708, Email : gizifk@ undip.ac.id
}

\begin{abstract}
Background : Pre-diabetes is a condition that precedes the onset of diabetes. Selection of the right kinds of food is one of the ways that can be done as a prevention of diabetes. One of the food ingredients that is associated with a decrease in blood glucose levels is yam bean (Pachyrrhizuserosus). The aim of this study is to determine the differences in fasting blood glucose levels before and after the administration of yam bean essence (Pachyrrhizuserosus) in pre-diabetic women.

Method : This study is a true experiment study with a control group pretest - posttest design. There were 30 subjects in this study with the criteria of, age of 40-50 years old, and fasting blood glucose (FBG) level of 100-125 $\mathrm{mg} / \mathrm{dl}$. The subjects were divided into 2 groups (treatment and control) randomly whereas each group consists of 15 subjects. The treatment group in this study was given yam bean essence that was made from 320 grams of yam bean fruit that was essenced using a juicer and the control group was given a low calorie syrup that was made from 2 tablespoons of syrup added with $+200 \mathrm{ml}$ of water for 21 days. The fasting blood glucose was measured using spectrophotometry method. Data of the differences in the fasting blood glucose was analyzed using Paired t-test, Indepedent sample t-test, Wilcoxon, and Mann-Whitney.

Result : The subjects' FBG level mean before the intervention in the treatment group is $108.53 \mathrm{mg} / \mathrm{dl}$ and after intervention is $102.53 \mathrm{mg} / \mathrm{dl}$. The subjects' FBG level mean before the intervention in the control group is 105.53 $\mathrm{mg} / \mathrm{dl}$ and after intervention is $109.4 \mathrm{mg} / \mathrm{dl}$. The subjects' delta mean of FBG level after intervention in the treatment group decreased significantly $(p<0.05)$ as much as $6 \mathrm{mg} / \mathrm{dl}$ and in the control group increased as much as $3.47 \mathrm{mg} / \mathrm{dl}$ but is not significant $(p>0.05)$. The statistical test showed significant difference $(p<0.05)$ between the two groups

Conclusion : There is a significant decrease in fasting blood glucose levels (p<0.05) as much as 6 mg/dl after the administration of yam bean essence that is made from 320 grams of yam bean fruit.
\end{abstract}

Keyword : yam bean (Pachyrrhizuserosus), fiber, fasting blood glucose levels.

\begin{abstract}
ABSTRAK
Latar Belakang : Prediabetes merupakan suatu keadaan yang mendahului timbulnya diabetes. Pemilihan jenis makanan yang tepat merupakan salah satu cara yang dapat dilakukan sebagai pencegahan diabetes. Bahan makanan yang dihubungkan dengan penurunan kadar glukosa darah adalah bengkuang (Pachyrrhizuserosus). Penelitian ini bertujuan untuk mengetahui perbedaan kadar glukosa darah puasa sebelum dan setelah pemberian sari bengkuang (pachyrrhizuserosus) pada wanita prediabetes.

Metode : Penelitian ini merupakan penelitian true experiment dengan control group pretest - posttest design. Subjek penelitian ini sebanyak 30 orang wanita dengan kriteria, 40-50 tahun, dan kadar glukosa darah puasa (GDP) 100-125 mg/dl. Subjek dibagi menjadi 2 kelompok (perlakuan dan kontrol) secara acak dimana masingmasing kelompok memiliki 15 orang subjek. Kelompok perlakuan pada penelitian ini diberi sari bengkuang yang terbuat dari 320 gram buah bengkuang yang diambil sarinya menggunakan juicer dan kelompok kontrol diberi sirup rendah kalori yang terbuat dari 2 sendok makan sirup dan ditambah $+200 \mathrm{ml}$ air matang selama 21 hari. Metode pengukuran kadar glukosa darah puasa adalah spektofotometri. Paired t-test, Indepedent sample t-test, Wilcoxon, dan Mann-Whitneydigunakan untuk menganalisis perbedaan kadar glukosa darah.

Hasil : Rerata kadar GDP subjek sebelum intervensi pada kelompok perlakuan sebesar $108.53 \mathrm{mg} /$ dl dan setelah intervensi sebesar $102.53 \mathrm{mg} / \mathrm{dl}$. Rerata kadar GDP subjek sebelum intervensi pada kelompok control sebesar $105.53 \mathrm{mg} / \mathrm{dl}$ dan setelah intervensi sebesar $109.4 \mathrm{mg} / \mathrm{dl}$. Rerata delta kadar GDP subjek setelah intervensi pada kelompok perlakuan mengalami penurunan yang bermakna ( $p<0.05)$ sebesar $6 \mathrm{mg} / \mathrm{dl}$ dan pada kelompok control mengalami peningkatan sebesar $3.47 \mathrm{mg} / \mathrm{dl}$ namun tidak bermakna(p>0.05). Uji statistik menunjukkan terdapat perbedaan yang bermakna ( $p<0.05)$ antar kedua kelompok.
\end{abstract}

Simpulan : Terdapat penurunan kadar glukosa darah puasa yang bermakna (p<0.05) sebesar 6 mg/dl setelah pemberian sari bengkuang yang terbuat dari 320 gram buah bengkuang.

Kata Kunci : bengkuang (Pachyrrhizuserosus), serat, kadar glukosa darah puasa

\footnotetext{
*)Penulis Penanggungjawab
} 


\section{PENDAHULUAN}

Diabetes merupakan salah satu penyakit tidak menular yang banyak terjadi di seluruh dunia.Diabetes adalah penyebab kematian keempat atau kelima terbesar di sebagian besar negara berpenghasilan tinggi dan terdapat bukti bahwa penderita diabetes meningkat di banyak negara berpenghasilan rendah dan menengah.Tahun 2010, penderita prediabetes dan diabetes mellitus (DM) pada orang dewasa usia 20-79 tahun di seluruh dunia mencapai 285 juta jiwa dan diperkirakan pada tahun 2030 meningkat hingga 439 juta jiwa ${ }^{1}$.Menurut WHO, pada tahun 2000 Indonesia menempati peringkat ke-4 untuk penderita diabetes terbanyak di seluruh dunia dengan jumlah sebanyak 8,4 juta jiwa dan diperkirakan akan meningkat menjadi 21,3 juta jiwa pada tahun $2030^{2}$. Berdasarkan riset kesehatan dasar (RISKESDAS) tahun 2013, jumlah penderita DM yang berumur diatas 15 tahun sebanyak $6,9 \%$ dari jumlah penduduk Indonesia ${ }^{3}$.

Diabetes mellitus ditandai dengan konsentrasi glukosa darah yang tinggi akibat gangguan produksi insulin, fungsi insulin, atau keduanya ${ }^{4}$.Prediabetes merupakan suatu keadaan yang mendahului timbulnya diabetes.Angka kejadian prediabetes dilaporkan terus mengalami peningkatan.Setiap tahun 4-9\% orang dengan prediabetes akan menjadi diabetes ${ }^{5}$. Sesuai dengan kriteria American Diabeic Association (ADA) prediabetes ditandai dengan glukosa darah puasa (GDP) antara 100-125 mg/d ${ }^{6}$.

Wanita di Indonesia mempunyai risiko mengalami gangguan toleransi glukosa lebih tinggi dibandingkan dengan pria.Komposisi lemak tubuh yang tinggi menyebabkan wanita cenderung lebih mudah gemuk yang berkaitan dengan risiko gangguan toleransi glukosa. Selain itu, tingkat aktifitas wanita Indonesia lebih rendah dibandingkan dengan pria ${ }^{13}$. Aktifitas fisik dapat mempengaruhi kadar GDP karena dapat mempengaruhi sensitivitas sel terhadap insulin ${ }^{20}$. Berkurangnya sensitivitas insulin juga dapat terjadi pada usia $>30$ tahun karena diketahui kadar glukosa darah puasa meningkat $1-2 \mathrm{mg} \%$ per tahun di usia $>30$ tahun. Hal ini berkaitan dengan adanya perubahan komposisi tubuh, menurunnya aktifitas fisik, perubahan pola makan, dan menurunnya sensitivitas reseptor insulin ${ }^{14}$.

Pencegahan diabetes atau pengendalian GDP dapat dilakukan dengan beberapa cara, antara lain: pemilihan jenis makanan yang tepat dan peningkatan aktivitas fisik ${ }^{4}$. Salah satu cara yang bisa dilakukan dalam pemilihan jenis makanan yang tepat adalah dengan memilih makanan dengan indeks glikemik (IG) yang rendah dan memiliki serat larut air. Salah satu bahan makanan yang memiliki IG rendah dan berpotensi menurunkan kadar glukosa darah adalah bengkuang. IG bengkuang sebesar 51 dimana angka tersebut masuk kedalam kategori rendah ${ }^{8}$.

Indeks Glikemikpangan merupakan indeks (tingkatan) pangan menurut efeknya dalam meningkatkan kadar glukosa darah. Bahan makanan yang mempunyai IG tinggi bila dikonsumsi akan meningkatkan kadar glukosa dalam darah dengan cepat dan tinggi. Sebaliknya, peningkatan kadar glukosa darah seseorang yang mengonsumsi bahan makanan dengan IG rendah berlangsung lambat. Kecepatan pencernaan karbohidrat berpengaruh penting terhadap peningkatan kadar glukosa darah. ${ }^{7}$ Serat larut air yang terdapat dalam bengkuang berperan dalam menurunkan kadar glukosa darah karena memperlambat absorpsi glukosa sehingga dapat mengendalikan kadar glukosa darah ${ }^{11}$. Serat larut air yang terdapat dalam bengkuang adalah inulin (oligasakarida).

Bengkuang adalah jenis umbi-umbian yang sering dikonsumsi oleh masyarakat, mudah didapat di Indonesia dan memiliki harga yang relatif murah.Bagian bengkuang yang dikonsumsi banyak orang adalah umbinya.Saat ini pemanfaatan sari bengkuang banyak digunakan dalam bidang kecantikan dan masih sangat sedikit dimanfaatkan di bidang kesehatan. Salah satu hasil olahan dari bengkuang yang dapat dikonsumsi dengan mudah adalah sari bengkuang dimana sari bengkuang didapatkan dengan caramenghaluskan bengkuang menggunakan juicer untuk diambil sarinya.Dari sebuah penelitian ditemukan kandungan zat gizi sari bengkuang mengandung senyawa polifenolat $3,063 \%$, flavonoid $2,603 \%$, alkaloid 1,517\%, vitamin B1 0,07mg, vitamin C 26 $\mathrm{mg}$, karbohidrat $13 \mathrm{gr}$, besi $0,8 \mathrm{mg}$, protein 1,6 gr, energi $53 \mathrm{kal}^{10}$.

Berdasarkan penelitian yang dilakukan pada tikus putih (Rattus norvegitus)yang diinduksi dengan alloksan, pemberian ekstrak bengkuang dengan dosis $2 \mathrm{ml}$ dan $5 \mathrm{ml}$ dapat menurunkan kadar glukosa darah tikus diabetes dari 300,14 $\mathrm{mg} / \mathrm{dl}$ menjadi $263,96 \mathrm{mg} / \mathrm{dl}$ dan $301,59 \mathrm{mg} / \mathrm{dl}$ menjadi $207,08 \mathrm{mg} / \mathrm{dl}$ dalam waktu 21 hari. Semakin besar dosis yang diberikan maka semakin turun kadar glukosa darah tikus ${ }^{11}$.

Penelitian pengaruh bengkuang terhadap penurunan glukosa darah pada tikus memang pernah dilakukan, namun belum ada penelitian pengaruh bengkuang terhadap perbaikan kadar glukosa darah pada wanita prediabetes. Oleh 
karena itu peneliti ingin melakukan penelitian mengenai perbedaan kadar glukosa darah puasa sebelum dan setelah pemberian sari bengkuang pada wanita prediabetes.

\section{METODE PENELITIAN}

Penelitian ini dilakukan di kantor Dirjen Perbendaharaan (DJPB) dan Badan Pertanahan Nasional (BPN) Kota. Jenis penelitian adalah true experiment dengan control group pretest - posttest design. Pelaksanaan penilitian telah mendapat persetujuan dari Komite Etik Fakultas Kedokteran Universitas Dipnegoro melalui terbitnya Ethical Clearance.

Subjek penelitian adalah karyawati kantor DJPB dan BPN yang diambil secara consecutive sampling. Besar subjek dalam penelitian adalah 30 orang. Kriteria inklusi subjek antara lain wanita usia 40 - 50 tahun, belum mengalami menopause, memiliki kadar glukosa darah puasa 100-125 $\mathrm{mg} / \mathrm{dl}$, tidak sedang hamil atau menyusui, tidak sedang mengonsumsi obat-obatan antihiperglikemia selama penelitian, tidak dalam keadaan sakit atau dalam perawatan dokter berkaitan dengan penyakit jantung koroner, diabetes mellitus, hipertensi, gagal ginjal, dan penyakit kronik lainnya, bersedia menjadi subyek penelitian dengan mengisi informed consent, tidak merokok dan tidak mengonsumsi alkohol, dan tidak memiliki riwayat keturunan diabetes mellitus.

Variabel bebas pada penelitian ini adalah sari bengkuang. Sari bengkuang diperoleh dari buah bengkuang dengan genus Pachyrrhizus dan spesies Pachyrrhizus erosus seberat 320 gram yang telah dikupas dan dicuci bersih. Setelah itu buah bengkuang diambil sarinya menggunakan juicer dengan merk Cosmos yang menghasilkan $\pm 250 \mathrm{ml}$ sari bengkuang.Sari bengkuang dikemas dalam gelas plastik yang kemudian ditutup rapat menggunakan alat cup sealer.Kandungan zat gizi pada sari bengkuang di uji di UPT Laboratorium Ilmu Gizi dan Pangan Universitas Muhammadiyah Semarang. Berdasarkan uji yang dilakukan sari bengkuang mengandung senyawa flavonoid 26,455\%, vitamin C 13.86 mg, oligosakarida 44.04 gr, dan serat 3.94 gr.

Variabel terikat dalam penelitian ini adalah kadar glukosa darah puasa dengan satuan $\mathrm{mg} / \mathrm{dl}$ yang diambil oleh petugas laboratorium "Permata" melalui pembuluh vena di lengan setelah subyek berpuasa selama 10 jam. Pengukuaran kadar GDP diuji dengan metode spektofotometri. Sampel darah diambil 2 kali, yaitu 2 hari sebelum intervensi untuk mengetahu kadar GDP sebelum intervensi, dan 1 hari setelah intervensi selesai (hari ke-22) untuk mengetahui kadar GDP setelah intervensi.

Variabel perancu dalam penelitian ini adalah asupan zat gizi. Data asupan zat gizi berupa karbohidrat, lemak, protein, dan serat diperoleh dengan cara mewawancarai subjek selama intervensi. Hasil penilaian rata-rata asupan karbohidrat, lemak, protein dan serat yang berasal dari makanan dan minuman selama intervensi dicatat pada formulir food recall 24 jam.Data yang diperoleh dihitung dalam bentuk URT dan dikonversikan kedalam satuan gram kemudian dihitung menggunakan program nutrisoft.

Prosedur pertama dalam penelitian ini adalah memberikan penjelasan mengenai maksud penelitian, metode, risiko, dan ketidaknyamanan yang akan dialami serta keuntungan yang diperoleh subjek penelitian. Setelah itu peneliti menawarkan kesediaan menjadi subjek penelitian. Subjek yang telah bersedia diminta untuk menandatangani informed consent. Selanjutnya, dilakukan pengukuran berat badan (BB) dan tinggi badan (TB) untuk mengetahui indeks massa tubuh (IMT), wawancara data umum subjek serta skrining kadar GDP.

Data yang dikumpulkan melalui wawancara adalah data umum subjek, data asupan makandan aktifitas fisik. Data yang dikumpulkan melalui pengukuran antropometri adalah data berat badan yang diperoleh melalui penimbangan dengan timbangan digital dan data tinggi badan yang diperoleh melalui pengukuran dengan microtoise. Data aktifitas fisik dikumpulkan menggunakan kuesioner aktivitas fisik baecke (1982). Dalam penelitian ini, pekerjuaan seluruh subjek sama, yaitu karyawati. Aktifitas fisik yang dimaksud adalah aktivitas saat berolahraga dan pada waktu luang. Aktifitas fisik subjek dihitung menggunakan rumus indeks aktifitas fisik olahraga dan aktifitas waktu luang. Pengkategorian aktifitas fisik adalah sangat aktif, aktif, cukup aktif, kurang aktif, dan sangat tidak aktif, dimana seluruh subjek yang termasuk dalam kriteria inklusi adalah subjek yang memiliki aktifitas fisik dalam kategori kurang aktif. Data status gizi subjek dihitung dengan menggunakan rumus IMT dengan kategori underweight, normal, overweight, dan obesitas (Depkes, 2003). Tidak ada pembatasan status gizi subjek dalam penelitian ini.

Skrining dilakukan pada 96 orang wanita yang bersedia diperiksa kadar GDP dan sebanyak 35 orang dari jumlah tersebut memenuhi kriteria inklusi menjadi subjek penelitian. Subjek yang memenuhi kriteria dibagi menjadi 2 kelompok menggunakan simple randomization. Kelompok 
pertama diberikan sari bengkuang sebanyak \pm 250 ml selama 21 hari, sedangkan kelompok kedua diberikan plasebo berupa air sirup rendah kalori. Plasebo terbuat dari 2 sendok makan sirup rendah kalori yang ditambahkan air sebanyak $\pm 200 \mathrm{ml}$. Dosis pemberian sari bengkuang berdasarkan ukuran rumah tangga (URT) buah bengkuang. Setelah pemberian sari bengkuang selama 21 hari, pada hari ke-22 dilakukan pengambilan darah pada kedua kelompok untuk mengetahui kadar glukosa darah puasa.

Data yang diperoleh dianalisis secara statistik. Gambaran karakteristik subjek dianalisis dengan analisis deskriptif. Uji normalitas data glukosa darah puasa sebelum dan setelah perlakuan menggunakan uji Shapiro Wilk. Data perbedaan kadar glukosa darah puasa sebelum dan setelah perlakuan pada kelompok perlakuan berdistribusi tidak normal sehingga diuji menggunakan Uji Wilcoxon, sedangkan data perbedaan kadar glukosa darah puasa sebelum dan setelah perlakuan pada kelompok kontrol berdistribusi normal sehingga diuji menggunakan Uji Paired t-test. Perbedaan penurunan kadar glukosa darah puasa kedua kelompok setelah perlakuan dianalisis dengan uji Independent $t$-test.

\section{HASIL PENELITIAN \\ Karakteristik Subjek}

Karakteristik subjek yang terdiri dari gambaran umum dan status gizi disajikan dalam tabel 1 .

Tabel 1. Karakteristik Subjek

\begin{tabular}{|c|c|c|c|c|c|c|}
\hline \multirow[t]{2}{*}{ Variabel } & \multicolumn{4}{|c|}{$\begin{array}{c}\text { Perlakuan } \\
(n=15)\end{array}$} & \multicolumn{2}{|c|}{$\begin{array}{c}\text { Kontrol } \\
(n=15)\end{array}$} \\
\hline & Mean \pm SD & $\mathbf{n}$ & $\%$ & Mean \pm SD & $\mathbf{n}$ & $\%$ \\
\hline $\begin{array}{l}\text { Umur } \\
40-50\end{array}$ & $46.73 \pm 3.10$ & 15 & 100 & $44.33 \pm 3.46$ & 15 & 100 \\
\hline \multicolumn{7}{|l|}{ Status Gizi } \\
\hline Normal $(18,5-22,9$ kg/m²) & $2601+506$ & 3 & 10 & $2389+374$ & 7 & 23.3 \\
\hline Overweight $\left(23-24.9 \mathrm{~kg} / \mathrm{m}^{2}\right)$ & $20.91 \pm 5.00$ & 3 & 10 & $23.89 \pm 3.74$ & 2 & 6.7 \\
\hline Obesitas (>25 kg/m²) & & 9 & 30 & & 6 & 20 \\
\hline Aktivitas Fisik & $1.53 \pm 0.02$ & 15 & 100 & $1.53 \pm 0.01$ & 15 & 100 \\
\hline
\end{tabular}

Subjek dalam penelitian ini berada pada kelompok umur 40-50 tahun, memiliki status gizi normal, overweight, dan obesitas, namun sebagian besar subjek memiliki status gizi obesitas, yang lebih banyak ditemukan pada kelompok perlakuan (30\%). Aktifitas fisik subjek pada penelitian ini termasuk dalam kategori kurang aktif.

\section{Asupan Zat Gizi Selama Intervensi}

Data asupan zat gizi selama intervensi disajikan untuk melihat perbedaan asupan zat gizi subjek selama intervensi pada kelompok perlakuan dan kontrol.

Tabel 3. Asupan Zat Gizi Selama Intervensi

\begin{tabular}{lccc}
\hline \multicolumn{1}{c}{ Variabel } & Perlakuan $(\mathbf{n = 1 4})$ & Kontrol $(\mathbf{n = 1 4})$ & \multirow{2}{*}{$\boldsymbol{p}$} \\
\cline { 2 - 3 } & Mean \pm SD & Mean \pm SD & \\
\hline Asupan energi & $1172.3 \pm 253.17$ & $1237.67 \pm 358.74$ & $0.569^{a}$ \\
Asupan protein & $36.49 \pm 8.56$ & $40.85 \pm 10.76$ & $0.217^{b}$ \\
Asupan lemak & $45.63 \pm 17.74$ & $39.69 \pm 13.75$ & $0.314^{a}$ \\
Asupan karbohidrat & $156.97 \pm 31.55$ & $184.65 \pm 60.82$ & $0.129^{a}$ \\
Asupan serat & $7.78 \pm 1.8$ & $8.39 \pm 2.43$ & $0.444^{a}$ \\
\hline
\end{tabular}

Keterangan: $a=$ Independent $t$-test, $b=$ Mann-Whitney

Tabel 3 menunjukkan tidak terdapat perbedaan asupan energi, protein, lemak,karbohidrat, dan serat yang bermakna antara kelompok perlakuan dan kontrol selama intervensi.
Rerata asupan selama intervensi kelompok kontrol lebih tinggi dari kelompok perlakuan.

Perbedaan Kadar Glukosa Darah Puasa Sebelum dan Setelah Intervensi 
Tabel 2. Perbedaan kadar GDP sebelum dan setelah intervensi

\begin{tabular}{|c|c|c|c|}
\hline \multirow{2}{*}{ Variabel } & Perlakuan $(n=15)$ & Kontrol $(n=15)$ & \multirow[b]{2}{*}{$p$} \\
\hline & Mean \pm SD & Mean \pm SD & \\
\hline GDP sebelum intervensi (mg/dl) & $108.53 \pm 8.83$ & $105.53 \pm 7.19$ & $0.532^{a}$ \\
\hline GDP setelah intervensi (mg/dl) & $102.53 \pm 7.83$ & $109.4 \pm 13.57$ & $0.101^{b}$ \\
\hline$\Delta \mathrm{GDP}(\mathrm{mg} / \mathrm{dl})$ & $-6.00 \pm 8.07$ & $3.47 \pm 10.04$ & $0.008^{b^{*}}$ \\
\hline$p$ & $0.016^{c^{*}}$ & $0.187^{d}$ & \\
\hline
\end{tabular}

Kelompok perlakuan mengalami penurunan kadar GDP yang bermaknasetelah pemberian sari bengkuang selama 21 hari. Pada kelompok perlakuan terdapat 10 orang subjek yang mengalami penurunan dan 4 orang subjek yang mengalami peningkatan kadar GDP serta 1 orang subjek yang memiliki kadar GDP yang tidak berubah. Pada kelompok kontrol terdapat 5 orang subjek yang mengalami penurunan dan 8 orang subjek yang mengalami peningkatan kadar GDP serta 2 orang subjek yang memiliki kadar GDP yang tidak berubah. Berdasarkan uji independent $t$ test, terdapat perbedaan perubahan kadar GDP ( $\triangle$ GDP) yang bermakna antara kelompok perlakuan dan kelompok kontrol. Penurunan kadar GDP pada kelompok perlakuan sebesar 5.53\%.

\section{PEMBAHASAN}

Seluruh subjek dalam penelitian ini adalah wanita, karena wanita memiliki risiko mengalami gangguan toleransi glukosa yang lebih tinggi dibandingkan dengan pria akibat komposisi lemak tubuh yang lebih tinggi dan aktifitas fisik yang lebih rendah sehingga lebih rentan mengalami kegemukan ${ }^{13}$. Usia subjek pada penelitian adalah usia 40-50 tahun baik pada kelompok perlakuan maupun kontrol. Diketahui kadar glukosa darah puasa meningkat $1-2 \mathrm{mg} \%$ per tahun di usia $>30$ tahun. Hal ini berkaitan dengan adanya perubahan komposisi tubuh, menurunnya aktifitas fisik, perubahan pola makan, dan menurunnya sensitivitas reseptor insulin ${ }^{14}$.

Berdasarkan Indeks massa tubuh atau IMT, subjek pada kelompok perlakuan lebih banyak termasuk dalam kategori obesitas (30\%), sedangkan pada kelompok kontrol paling banyak berada pada kategori overweight $(23.3 \%)$. IMT berhubungan dengan kadar lemak tubuh total sehingga dapat digunakan untuk mengidentifikasi kelebihan berat badan dan obesitas. Seseorang dengan obesitas terutama obesitas sentral cenderung lebih berisiko menderita diabetes karena terjadi resistensi insulin ${ }^{5}$. Resistensi insulin pada penderita obesitas sentral terjadi karena lemak viseral berperan dalam serangkaian perubahan sekresi adipokin yang menghasilkan sejumlah sitokin pro-inflamasi seperti Tumor Necrosis
Factors (TNF- $\alpha$ ), IL-1, IL-6, resistin dan PAI-1 yang dapat mengganggu aktifitas normal insulin dalam sel lemak dan sel otot serta toksisitas pada sel- $\beta$ pankreas. Selain itu, terjadi peningkatan kadar asam lemak dalam darah dan peningkatan produksi glukosa hepatik akibat penumpukan lemak dalam hati sehingga meningkatkan risiko terjadinya DM tipe $\mathrm{II}^{15,16}$.

Aktifitas fisik subjek pada kelompok perlakuan maupun kelompok kontrol yang dikumpulkan menggunakan kuesioner aktifitas fisik Baecke termasuk dalam kategori kurang aktif.Kurangnya aktifitas fisik merupakan salah satu penyebab kelebihan berat badan ${ }^{13}$.Subjek penelitian pada kelompok perlakuan dan kelompok kontrol memiliki kebiasaan olahraga dengan frekuensi 1-2 kali seminggu selama 30-60 menit.Jenis olahraga yang dilakukan subjek adalah jalan kaki dan senam.Olahraga memperbaiki metabolisme glukosa dan sensitifitas insulin, memberikan efek yang menguntungkan bagi metabolisme karbohidrat dan lemak, meningkatkan asupan glukosa oleh otot, serta berperan dalam penurunan berat badan ${ }^{19}$.

Rerata kadar GDP wanita prediabetes pada kelompok perlakuan sebelum intervensi dalam penelitian ini diketahui sebesar $108.53 \mathrm{mg} / \mathrm{dl}$ dan rerata kelompok kontrol sebelum intervensi adalah $105.53 \mathrm{mg} / \mathrm{dl}$. Berdasarkan hasil uji statistik tidak ditemukan adanya perbedaan kadar GDP yang bermakna antara kelompok perlakuan dan kelompok kontrol sebelum intervensi, sehingga dapat dikatakan kadar GDP kedua kelompok adalah homogen.Pemberian sari bengkuang selama $\pm 250 \mathrm{ml}$ yang berasal dari 320 gram buah bengkuang selama 21 hari terbukti dapat menurunkan kadar GDP secara bermakna sebesar 6 $\mathrm{mg} / \mathrm{dl}$ atau sebesar $5.53 \%$.

Peran sari bengkuang dalam menurunkan kadar glukosa darah diketahui berasal dari kandungan oligosakarida bengkuang. Kandungan oligosakarida dalam bengkuang sebesar 44.04 gr. Oligosakarida atau inulin adalah jenis karbohidrat kompleks.Inulin termasuk serat larut air dimana serat larut air dapat digunakan sebagai terapi hipoglikemik.Peran serat larut air sebagai terapi hipoglikemik adalah dengan memperbaiki 
sensitivitas insulin dan menurunkan kebutuhan insulin.Sama seperti serat larut air lainnya, inulin akan meningkatkan viskositas lambung sehingga menurunkan laju penyerapan glukosa dan menunda pengosongan lambung sehingga membuat rasa kenyang lebih lama, menyebabkan perubahan level hormon di saluran cerna seperti gastric inhibitory polipeptide (GIP), glukagon, dan somatostatin yang berpengaruh pada motilitas saluran pencernaan, penyerapan zat gizi, dan sekresi insulin. Apabila penyerapan glukosa lambat maka sekresi insulin tidak akan berlebihan sehingga akan menurunkan kebutuhan insulin dan sensitivitas insulin jadi meningkat ${ }^{17}$.

Selain itu, bengkuang juga merupakan salah satu bahan makanan yang memiliki beban glikemik yang rendah dengan nilai $51^{8}$. Makanan dengan beban glikemik rendah akan menurunkan laju penyerapan glukosa dan menekan sekresi hormon insulin pankreas sehingga tidak terjadi lonjakan kadar glukosa darah ${ }^{18}$. Berdasarkan sebuah penelitian yang sudah dilakukan sebelumnya, pemberian ekstrak bengkuang dengan dosis $2,7 \mathrm{ml} / 200 \mathrm{gr} \mathrm{BB} /$ hari dan dosis $5,4 \mathrm{ml} / 200 \mathrm{gr}$ $\mathrm{BB} /$ hari pada tikus hiperglikemik selama 21 hari dapat menurunkan kadar glukosa darah dari 300,14 $\mathrm{mg} / \mathrm{dL}$ menjadi $263,96 \mathrm{mg} / \mathrm{dL}$ dan $301,59 \mathrm{mg} / \mathrm{dL}$ menjadi $207,08 \mathrm{mg} / \mathrm{dL}^{11}$.

Rerata kadar GDP pada kelompok kontrol mengalami peningkatan sebesar $3.47 \mathrm{mg} / \mathrm{dl}$.Hal ini kemungkinan disebabkan karena pada kelompok kontrol tidak terdapat peningkatan asupan serat seperti pada kelompok perlakuan yang berasal dari sari bengkuang.Asupan serat yang rendah merupakan salah satu penyebab tingginya kadar GDP. Selain itu, meskipun hasil uji statistik asupan karbohidrat antara kedua kelompok tidak bermakna, namun asupan karbohidrat pada kelompok kontrol lebih tinggi dibandingkan dengan kelompok perlakuan.Hal ini sesuai dengan hasil sebuah penelitian yang dilakukan pada wanitadi Amerika Serikat dimana hasilnya menunjukkan diit yang tinggi karbohidrat dan rendah serat dihubungkan dengan meningkatkatnya risiko diabetes tipe $2^{21}$.Pada orang yang sensitivitas insulinnya menurun, konsumsi karbohidrat yang tinggi dapat menyebabkan berkurangnya penggunaan glukosa oleh otot dan jaringan lemak, dan terjadi peningkatan glukoneogenesis di hati

\section{SIMPULAN}

Terdapat penurunan kadar glukosa darah puasa yang bermakna sebesar $6 \mathrm{mg} / \mathrm{dl}$ setelah pemberian sari bengkuang sebanyak $250 \mathrm{ml}$ selama 21 hari.

\section{SARAN}

1. Dilakukan uji laboratorium untuk inulin dan serat larut air untuk mengetahui jumlah inulin dan serat larut air yang terkandung dalam sari bengkuang.

2. Dilakukan pengambilan data asupan zat gizi sebelum intervensi,

\section{DAFTAR PUSTAKA}

1. Sicree R, Shaw J, Zimmet P. The global burden: diabetes and impaired glucose tolerance. International Diabetes Foundation $4^{\text {th }}$ edition.

2. Wild S, Roglic G, Green A, Sicree R, King H. Global prevalence of diabetes: Estimates for the year 2000 and Projections for 2030. Diabetes Care 2004;27:1047-53

3. Badan Penelitian dan Pengembangan Kesehatan. Riset Kesehatan Dasar. Jakarta: Kementrian Kesehatan Republik Indonesia; 2013.

4. Franz MJ. Medical nutrition therapy for diabetes mellitus and hypoglycemia of nondiabetic origin. Dalam : Mahan LK, Stump ES. Krause's Food, Nutrition and Diet Therapy $13^{\text {th }}$ edition. Pensylvania : Saunders; 2012. Hal 675-682.

5. Perkumpulan Endokrinologi Indonesia. Konsensus pengelolaan dan pencegahan diabetes melitus tipe 2 di Indonesia. Jakarta : PB. PERKENI; 2011.p.3$17,30-31$

6. American Diabetic Association. Standards of medical care in diabetes. 2012. [cited 2014 March 19 ${ }^{\text {th }}$. Available from URL: http://care.diabetesjournals.org/content/35/Supple ment 1/S11.full.pdf+html

7. Warta Penelitian dan Pengembangan Pertanian. Sehat dengan Pangan Indeks Glikemik Rendah. 2007; 29 (3).

8. Robbins Sam. Glycemic Index (GI) Food Chart. [cited 2014March 24 ${ }^{\text {th }}$ ] Available from: URL: http://www.hflsolutions.com/healthtips/weightloss/ GI_foodchart.pdf

9. Kusharto, Clara M. SeratMakanan Dan Peranannya bagi kesehatan. Jurnal Gizi dan Pangan. IPB 2006; 1:45-54.

10. Setyadi Ahmad Wasis, Junianto F, Erni Yulianti. Pengaruh Sari Bengkuang (Pachryrrhizua Erosus) terhadap Penurunan Kolesterol pada Tikus Putih (Rattus Norvergicus) di Laboratorium Kimia Universitas Muhammadiyah Malang. 2013.

11. Pengaruh Pemberian Ekstrak Bengkuang (Pachyrhizus erosus) Terhadap Kadar Gula Darah, Kadar Immunoglobulin A (IgA) dan Vili Usus pada Tikus Putih (Rattus Norvegitus) Diabetes Mellitus. Universitas Andalas 2012.

12. Tensiska. 2008. Probiotik dan prebiotik sebagai pangan fungsional.Universitas Padjajaran 2008.

13. Soegondo S, Soewondo P, Subekti I. Penatalaksanaan diabetes melitus terpadu. Jakarta : Pusat Diabetes dan Lipid RSUP Nasional Dr. 
Cipto Mangunkusumo Fakultas Kedokteran Universitas Indonesia; 2002

14. Soegondo S. Obesitas. Dalam: Buku ajar ilmu penyakit dalam Jilid III. edisi IV. Jakarta: Balai Penerbit Fakultas Kedokteran, Universitas Indonesia; 2006.p.1919-24

15. Mlinar B, Marc J, Janez A, Pfeifer M. Molecular mechanisms of insulin resistance and associated diseases. 375 (2007); 20-35

16. Haffner SM. Abdominal obesity, insulin resistance and cardiovascular risk in pre-diabetes and type 2 diabetes. Eur Heart J Supplements. 2006; B20-25

17. Corwin Elizabeth J. Pankreas dan Diabetes Mellitus. Dalam : Buku Saku Fisiologi. edisi 3. Jakarta: EGC; 2009.p.618-628.

18. Willet WC, Manson JA, and Liu S. Glykemic Index, Glycemic Load, and Risk of Type 2 Diabetes.Am J Clin Nutr., 2002 ; 76: 274 - 80.

19. Guyton AC, Hall JE. Insulin, glucagon, dan diabetes mellitus. Dalam : Buku ajar fisiologi kedokteran edisi 11. Jakarta : EGC; 2007. Hal 1010-28.

20. Bender DA. Nutrition and metabolism $4^{\text {th }}$ edition. CRP Press. Hal 83-86

21. Schulze MB, Liu S, Rimm EB, Manson JE, Willet WC, Hu FB. Glycemic index, glycemic load, and dietary fiber intake andincidence of type 2 diabetes in younger and middle-aged women. Am J Clin Nutr2004;80:348 -56.

22. Rolfes SR, Pinna K, Whitney E. Diabetes mellitus. Dalam : Understanding normal and clinical nutrition $2^{\text {nd }}$ edition. USA : Wadsworth Cengage Learning; 2009. Hal 811-813. 